\title{
PENGENDALIAN MUTU PADA EMPING MELINJO DI UD. INTISARI JAYA DI YOGYAKARTA JOMBLANG PALBAPANG BANTUL.
}

\author{
Mahrus Ali ${ }^{1}$, Anita Wulandari ${ }^{2}$, Siwidyah Desi Lastianti ${ }^{3}$ \\ ${ }^{1,3}$ Universitas Merdeka Surabaya \\ ${ }^{2}$ Politeknik Surabaya \\ Email: sengkomahrus@gmail.com
}

\begin{abstract}
ABSTRAK
Tulisan ini bertujuan untuk mengulas tentang Kontrol Kualitas pada proses Produksi untuk memberikan pemahaman dan kesadaran tentang pentingnya mebuat Kontrol Kualitas pada proses Produksi yang penting untuk meningkatkan produktivitas produk . Di UD. Intisari Jaya merupakan unit dari UD. Pengolah Emping Melinjo di Yogyakarta kabupaten Bantul Struktur organisasinya yang berbentuk lini dan staf. Jumlah tenaga kerjanya 57 orang dimana jumlah karyawan bagian produksi berjumlah 50 orang.Pengendalain mutu yang dilakukan oleh UD. Intisari Jaya dimulai dari bahan baku, tiap tahapan proses produksi sampai produk akhir yang dihasilkan. Pengendalian mutu bahan baku bertujuan untuk mendapatkan bahan baku yang sesuai dengan standart yang ditetapkan oleh perusahaan. Pengendalian mutu bahan baku pada emping, melinjo yang benar-benar tua dan biji melinjo yang keras warna kulinya kuning atau warna merah. Kegiatan pengendalian mutu proses dilaksanakan selama proses dengan tujuan untuk mengetahui penyimpangan yang terjadi sedini mungkin sehingga dapat diambil tindakan perbaikan. Pengendalian mutu proses produksi emping dilakukan pada tiap-tiap tahapan proses produksi. Pengendalian mutu produk akhir dilakukan dengan cara uji fisik dan khemis. Uji fisik dilakukan dengan cara uji visual yang meliputi warna dan bentuk, sedangkan uji khemis dilakukan dengan cara melalui DEP. KES setiap 1 tahun.
\end{abstract}

Kata kunci: Pengendalian Mutu, Emping melinjo di UD. Intisari Jaya.

\section{PENDAHULUAN}

Di Indonesia Tanaman melinjo tumbuh hampir di setiap daerah terutama di Pulau Jawa, Aceh, Sulsel, Sumsel, Pulau Lombok dan lain-lain. Di Pulau Jawa kira-kira 3.701 ha , meliputi Serang 1.096 ha, Bantul 345 dan Pacitan 2.260 ha dan masih terdapat areal di beberapa daerah lainnya yang tidak terlalu luas. Pada tahun 2000 produksi melinjo mencapai 141.116 ton.

Melinjo banyak manfaatnya, hampir seluruh bagian tanaman melinjo dapat dimanfaatkan terdiri dari daun muda, bunga, kulit biji tua, dapat digunakan sebagai bahan sayuran yang cukup populer dikalangan masyarakat bahkan kulit tua setelah diberi 
bumbu kemudian digoreng menjadi makanan ringan (gangsir) yang cukup lezat. Hampir semua makanan yang berasal dari tanaman melinjo mempunyai kandungan gizi yang cukup tinggi, selain karbohidrat juga mengandung lemak, protein, mineral, dan vitamin(Ali, 2015).

Buah melinjo setelah panen tidak langsung dijual tetapi disimpan sebagai persediaan disaat tidak musim. dan dijadikan produk jadi yang menjadi nilai lebih tinggi Tempat penyimpanan yang baik adalah tempat terbuka dan dingin. Penyimpanan yang terlalu lama yaitu diatas tiga bulan akan mempengaruhi kualitas. Hasil panen yang melimpah membuat sebagian buah melinjo rusak karena tidak tertanggulangi oleh para petani, untuk itu diperlukan penanganan dan teknologi untuk menanggulangi buah melinjo yang melimpah tersebut agar tahan lama dan tidak rusak.

Buah melinjo merupakan salah satu produk pertanian yang memiliki kandungan protein cukup tinggi. Selama ini pemanfaatan biji melinjo menjadi bahan olahan yang memiliki masa simpan retif lama dan bernilai ekonomis yang tinggi, maka diperlukan pengolahan buah melinjo menjadi emping dengan berbagai macam rasa yang diperoses dengan cara penyangrai, pengupasan, penumbukan dan pembumbuan yang mempunyai harga yang cukup tinggi, maka perlu adanya perlakuan khusus untuk menghasilkan produk yang bermutu(Ali, 2017).

Proses pengolahan merupakan salah satu bagian penting dari rantai industri, tanpa adanya proses tersebut peningkatan produk emping yang telah dicapai selama ini akan sia-sia, Pengolahan ini bertujuan untuk mempertahankan mutu emping .

Maka perlu adanya pengendalian mutu bertujuan untuk menjaga kepercayaan konsumen tehadap produk yang dihasilkan, terutama di Indonesia pegendalian kualitas terhadap emping sebagai produk akhir dari proses pengolahan melinjo menjadi emping yang mempunyai beraneka macam rasa yang dapat memiliki harga semakin tinggi maka mengakibatkan masyarakatpun menginginkan peningkatan kualitas emping. Emping yang diinginkan masyarakat adalah yang rasaya manis, rasa pedas dan rasa gurih.dan emping benar-benar emping yang berkualitas layak untuk dikonsumsi siapa saja Untuk mendapatkan emping dengan karakteristik di atas maka yang perlu dilakukan adalah melakukan pengendalian selama proses pemerolehan bahan baku, proses pembuatan emping dan teknik pengemasan dan penyimpanan setelah emping di produksi. 
UD. Intisari Jaya adalah industri bersakala kecil yang bergerak dibidang pengolahan melinjo menjadi emping yang dapat mentrasformasikan kebutuhan konsumen sebangai camilan dengan produk emping yang dapat bersaing dengan perusahan yang lainnya.

\section{HASIL DAN PEMBAHASAN}

\subsection{Ganbaran Umum Industri}

UD. Intisari Jaya suatu industri pengolahan emping melinjo yang berdiri pada tahun 1993 dan berjalan secara turun temurun. UD. Intisari Jaya berada di Jalan Raya Bantul Dusun Jomblang Palbapang Kecamatan Bantul. Industri ini dirintis oleh Ibu Sudi Pranoto. Pada awalnya Emping melinjo yang diproduksi hanya emping melinjo tawar saja dan tidak menggunakan merk,usaha masih sederhana,dan produksinya hanya dikenal pada lingkungan setempat.

Pada awal tahun 2003 industri ini mengalami kemajuan yang sangat pesat dan Emping melinjo yang diproduksi sudah mengunakan merk dan dikenal oleh banyak konsumen sehingga Ibu Sudi Pranoto mulai memperluas wilayah pemasaran diberbagai wilayah seperti Pontianak, Balikpapan, Bandung, Bayuwangi, Jember, Probolinggo dan Tasik Malaya.

Permasalahan yang pertama timbul setelah pendirian Perajin Emping melinjo ini tidak ada masalah pada warga sekitar, karena perajin emping melinjo pada proses produksi tindak mengganggu pada warga sekitarnya,sebab ibu sudi mengrekrut warga sekitar dijadikan sebangai tenaga kerja dari yang muda yang putus sekolah dan ibu - ibu rumah tangga juga dijadikan untuk tenaga kerja. Masalah lainnya yaitu cuaca dan pasar. Biasanya sekali produksi dimusim kemarau hanya butuh dua hari sampai tiga hari, tetapi pada saat musim hujan bisa 7 sampai 10 hari artinya rata - rata waktu produksi adalah 10 hari. Prokdusi yang dilakukan UD. Intisari Jaya adalah sesuai permintaan pasar. UD. Intisari Jaya mengolah 2 kwintal bahan baku dan mengasilkan satu setegah kwintal produk setiap produksi. Produksi akan dikurangi jika permintaa pasar sedikit dan stok masih banyak. 


\subsection{Tenaga kerjaan}

Jumlah tenaga kerja UD. Intisari Jaya sebanyak 57 orang, terdiri dari satu pemimpin, tujuh tenaga kerja tetap dan lima puluh orang tenaga kerja harian. perekrutan tenaga kerja diambil dari lokasi industri dan juga di ambil dari berbagai kampung tetangga seperti Kisik, Mandingan, Klebakan, Dagen, Bambanglipuro dan Kersen, karna proses produksi dikerjakan dirumahnya masing - masing sehingga pekerja sambil melakukan pekerjaan rumah. UD. Intisari Jaya dapat dilihat pada tabel 4 sebangai berikut:

Tabel 1. Jumlah Tenaga Kerja Industri Emping Belinjo UD. Intisari Jaya.

\begin{tabular}{ll}
\hline \multicolumn{1}{c}{ Kedudukan } & Jumlah Tenaga Kerja \\
\hline Pimpinan & 1 orang \\
Bagian pembelian & 2 orang \\
Bagian pemasaran & 2 orang \\
Bagian administrasi dan keuangan & 2 orang \\
Bagian produksi & 50 orang
\end{tabular}

Sumber : UD. Intisari Jaya (1993)

\subsection{Upah dan Sistem pengupahan}

Upah adalah penganti atas jasa yang telah diserahkan kepada pihak majikan.pelaksaan pembayaran upah UD. Intisari Jaya berdasarkan hasil pekerja (peace work) pada proses produksi. Upah ini didasarkan pada pendapatan produksi $2000 / \mathrm{kg}$. apabila hasil produksinya banyak maka upah yang diterima akan bertambah banyak.Pembayaran untuk pekerjaan standar UD. Intisari Jaya ada dua bagian yaitu:

1. bagian I yaitu tenaga kerja tetap tujuh orang.Tenaga kerja tetap ini dibayar Rp.15.000,- perharinya. Yang termasuk proses pembumbuan,penjemuran dan pengemasan.

2. Bagian II yaitu tenaga kerja kasar yang termasuk pada proses produksi, terdiri dari 50 orang tenaga kerja ini dibayar 2000/ kg sesuai banyaknya hasil produksi semakin banyak maka upah yang diterima juga akan bertambah.

Selain upah, tenaga kerja UD. Intisari Jaya diberikan kompensasi lainya yaitu diberi makan camilan suguhan roti dan diberi makan setiap harinya. 


\subsection{Jam Kerja dan Waktu Kerja Istirahat}

Jam kerja di industri Emping Belinjo UD. Itisari Jaya terbagi menjadi dua bagian yaitu pukul 08.00 - 11.30 kemudian dilanjukan pada pukul 13.00 - 16.00. waktu istirahat sebanyak satu setenggah jam $11.30-13.00$.

\subsection{Proses Produksi}

Karakteristik bahan baku dan proses produksi yang baik menetukan mutu yang dihasilkan.Bahan baku utama pembuatan emping adalah melinjo. Tanaman melinjo ini selain ditaman di perkebunan oleh petani juga ditanam di pekarangan rumah yang mempunyai rasa yang khas. Oleh sebab itu merupakan pilihan yang tepat untuk bahan baku emping. Produksi emping ini yang paling bagus hasil produksinya melinjo yang tidak terlalu kering, karna pada proses pembuatan yang setenggah kering itu yang paling bagus hasil produknya pada saat ditumbuk.

UD. Intisari Jaya mengunakan bahan baku utama adalah melinjo, bijinya yang besar berwarna putih. Karena Kandungan protein pada melinjo ini cukup tinggi dari pada biji bijian yang lainnya. Bahan baku, UD. Intisari Jaya berasal dari hasil pertanian disekitar Industri,dan berasal dari desa tetangga, berkisar satu ton sampai dua ton UD. Intisari jaya mengirim berkisar dua sampai empat kwintal produk emping kepada distributor. UD. Intisari Jaya memproduksi emping sesuai dengan permintaan pasar.

\subsection{Bahan Pembantu}

Bahan pembantu yang digunakan UD. Intisari Jaya antara lain, garam, gula, lombok besar, bawang putih, ketumbar, penyedap rasa, dan pewarna.Bahan pembantu sangat penting untuk mengasilkan ouput dan daya tarik konsumen, selain itu dapat menentukan produk yang diingikan.

Pewarna digunakan untuk memperbaiki penampilan. Pewarna yang digunakan adalah pewarna makan yang berwarna merah. Setiap memproduksi satu kwintal bahan baku membutuhkan dua sampai emapat sendok pewarna . Biasanya rasa dan mutu emping melinjo dapat dilihat dari warna, sebab warna juga membawa sugesti yang mana semakin merah warna emping melinjo maka rasanya enak dan mutunya tinggi.

\subsection{Proses pembuatan emping}

Metode proses yang tepat akan menghasilkan output yang sesuai dengan standar industri. Tahapan proses pembuatan emping yaitu; 


\section{Penimbangan I}

Pada tahap ini bahan ditimbang menggunakan timbangan yang sederhana yang mempunyai tingkat ketelitian yang rendah yaitu timbangan duduk.Penimbangan ini bertujuan untuk mengetahui berat bahan baku yang akan di proses. Penimbangan setiap $20 \mathrm{~kg}$ biji melinjo.

2. Penyangraian

Pada tahap ini bahan disangrai setengah matang dengan menggunakan pasir supaya pada saat disangrai tidak gosong dan sesuai dengan yang diinginkan. Dengan waktu lama penyagrai selama \pm 15 menit dengan suhu $\pm 45-50^{\circ} \mathrm{C}$. Setiap satu gegam tangan.

3. Pengupasan

Pengupasan ini bertujuan untuk membersihkan kulit tempuruh melinjo sebelum ditumbuk supaya dalam proses penumbukan dihasilkan emping yang bagus. Pengupasan dilakukan selama satu menit dengan keadaan yang masih panas dengan suhu $\pm 45-50^{\circ} \mathrm{C}$.

4. Penumbukan danging biji melinjo

Penumbukan ini bertujuan untuk membentuk emping yang kita inginkan penumbukan ini dilakukan selama \pm 5 menit ditumbuk dengan cara satu-persatu biji melinjo yang ditumbuk sebanyak 3-4 biji melinjo agar hasilnya bisa seragam, penumbukan dilakukan ketika keadaan masih panas dengan suhu $\pm 45^{\circ} \mathrm{C}$.

5. Penjemuran I

Setelah biji melinjo ditumbuk kemudian dijemur diatas alat penjemuran kemudian dijemur sampai kering. Penjemuran I dilakukan selama \pm 7 jam apabila cuaca cerah. Dan lebih lama pada cuaca berawan.

6. Pemberian Bumbu

Setelah emping kering kemudian bahan dibumbui. Pemberian bunbu dilakukan dengan meredam bahan kedalam bak bumbu dan diaduk-aduk selama \pm 15 menit.

7. Penjemuran II

Penjemuran ini dilakukan setelah emping dibumbui. Dan merupakan proses penjemuran yang terakhir sebelum dikemas. Pada proses Penjemuran ini emping harus benar-benar kering.Penjemuran dilakukan selama \pm 10 jam pada cuaca cerah dan lebih lama pada cuaca berawan. 


\section{Pengangin-anginanan}

Setelah itu emping Diangin-anginkan bertujuan untuk mendinginkan emping denga suhu $\pm 30^{\circ}$.C Pada proses ini dilakukan selama \pm 15 menit.

9. Penimbangan II

Pada tahap penimbangan II merupakan proses penimbangan yang terakhir ketika produk mau dikemas.proses penimbangan ini dilakukan menimbang bahan 400gram dan 500gram emping.

10. Pengemasan

Pengemasan merupakan tahap terakhir dari suatu rangkaian proses produksi.Produk emping dikemas dengan baik agar produk terhindar dari kerusakan akibat kontak langsung dengan lingkungan. Pengemasan juga berfungsi untuk mempermudah penyimpanan dan penggunaannya. Bahan pengemasan yang digunakan adalah plastik makanan khusus pengemas emping. Karena plastik yang digunakan adalah sejenis PP (Polypropylene). Pengemasan dilakukan selama \pm 15 menit setiap 400gram dan 500 gram emping.

Tabel 2: Standar Proses Emping Melinjo

\begin{tabular}{l|ll}
\hline \multicolumn{1}{c|}{ Hasil Pengamatan di Lapang } & \multicolumn{3}{|c}{ Syarat Standar mutu } \\
\hline $\begin{array}{l}\text { Penyangrai emping melinjo denga suhu } \\
\pm 45-50^{\circ} \mathrm{C} \text {. lama penyagrai selama } \pm 15 \\
\text { menit. }\end{array}$ & Suhu sangrai $50^{\circ} \mathrm{C}$ \\
\hline $\begin{array}{l}\text { Pengupasan kulit tempuruh dengan } \\
\text { keadaan masih panas dengan suhu } \pm \\
45^{\circ} \mathrm{C} \text { lama pengupasan 1 menit. }\end{array}$ & $\begin{array}{l}\text { Dengan suhu pengupasan } 45^{\circ} \mathrm{C}, \\
\text { memudahkan untuk mengupas kulit } \\
\text { tempuruh. }\end{array}$ \\
\hline $\begin{array}{l}\text { Penumbukan danging biji melinjo } \\
\text { dilakukan selama } \pm 5 \text { menit,keada yang } \\
\text { masih panas dengan suhu } \pm 45^{\circ} \mathrm{C}\end{array}$ & $\begin{array}{l}\text { Dilakukan selama } 5 \text { menit dalam } \\
\text { keadaan masih panas dengan suhu } 45^{\circ}\end{array}$ \\
\hline $\begin{array}{l}\text { Penjemuran I dilakukan selama } \pm 7 \text { jam } \\
\text { dengan cuaca cerah. }\end{array}$ & Maksimum 7 dengan ketentuan cuaca \\
$\begin{array}{l}\text { Dibumbui dilakukan dengan meredam } \\
\text { bahan kedalam bak bumbu selama } \pm 15 \\
\text { menit. }\end{array}$ & Maksimum 15 menit \\
\hline $\begin{array}{l}\text { Penjemur II dilakukan selama } \pm 10 \text { jam } \\
\text { pada cuaca cerah dan lebih lama pada } \\
\text { cuaca berawan. }\end{array}$ & Maksimum 10 jam dengan ketentuan \\
cuaca cerah
\end{tabular}


\begin{tabular}{lll|l} 
Penimbangan dilakukan selama \pm 5 & Maksimum 400gram dan 500gram
\end{tabular} menit setiap 400gram dan 500gram emping.

\begin{tabular}{lll|l} 
Pengemasan dilakukan selama \pm 15 & Maksimum 400gram dan 500gram
\end{tabular}

menit setiap 400gram dan 500gram

emping.

Sumber: SINAR TANI Edisi 3 - 9 Oktober 2007) BPTP YOGYAKARTA

\section{MESIN DAN PERALATAN}

\subsection{Mesin Dan Peralatan}

Mesin dan peralatan yang digunakan dalam proses pembuatan emping di UD. Intisari Jaya masih sangat sederhana karena prose pengolahan masih mengunakan tenaga manusia dan alat sederhana. Mesin dan peralata yang dingunakan UD. Intisari Jaya adalah sebangai berikut:

1. Timbangan

Dalam proses pembutan emping dingunakan timbangan yang sederhana dan mempunyai ketelitian yang rendah. Timbangan yang digunakan adalah timbangan duduk untuk produk dan timbangan kwintal untuk bahan baku. Timbangan duduk mempunyai fungsi untuk menimbang produk jadi yang bekapasitas maksimum lima kilogram. Timbangan kwintal digunakan untuk menimbang bahan baku.

2 Alat penumbuk

Alat penumbuk yang dingunakan dalam pembuatan emping masih tradisional yaitu mengunakan palu yang sudah dibentuk panjang $15 \mathrm{~cm}$ dan lebar $3 \mathrm{~cm}$.

3. Batu landasan pemipih

Batu landasan ini berfungsi sebagai telanan untuk penumbukan biji melinjo dan di beri alas plastik. Batu ini mempunyai diameter panjang $30 \mathrm{~cm}$ dan lebar $15 \mathrm{~cm}$ dengan ketebalan 7 inci.

4. Wajan

Wajan digunakan untuk meyangrai biji melinjo yang mempunyai diameter besar 30 cm supaya untuk mepermudah mengupas kulit ari pada biji melinjo.

5. Serok

Serok digunakan untuk mengaduk waktu penyangrai bukan hanya digunakan untuk pengaduk saja tapi juga digunakan untuk pengambilan dari wajan. 


\section{Plastik}

Plastic digunakan untuk alas pada waktu penumbukan,plastic yang digunakan plastic yang tebal tidak mudah sobek.

7. Bak plastik

Bak plastik berfusing sebangai wadah pembumbuan emping.bak yang digunakan mempunyai ukuran besar dengan diameter $45 \mathrm{~cm}$ dan tinggi $19 \mathrm{~cm}$.

8. Perangkat penjemuran

Dapat dingunakan alat penjemuran kesek yang terbuat dari bambu yang di lapisi karung yang baru.yang ber ukuran panjang 1 meter lebar $50 \mathrm{~cm}$.

9. Kardus

Kardus ini berfungsi sebangai penyimpan produk selain itu kardus juga dingunakan sebangai pengemas lapisan luar. Agar pada waktu pengiriman emping tidak mudah hancur atau remuk.

10. Kertas semen

Kertas semen dingunakan untuk pengemas atau sebangai sampul luar saja pada waktu pengiriman,supaya emping tidak hancur pada saat perjalan.

\subsection{Tugas Khusus dan Pengendalian mutu}

Pengendalian mutu proses berarti menjaga dan memperbaiki mutu produk di dalam proses produksi. Proses produksi dalam artian sempit merupakan proses dimana bahan mentah diubah manjadi barang jadi. Pengendalian mutu produk pangan berkaitan erat dengan sistem pengolahan, meliputi bahan baku, proses, produk akhir dan penyimpanan yang terjadi. Ada tiga kegiatan yang dilakukan dalam pengendalian mutu yaitu penetapan standart, penilaian kesesuaian denga standart (inspeksi dan pengendalian), serta melakukan tindak koreksi (prosedur uji).

Pengendalian mutu yang dilakukan oleh UD.Intisari Jaya bertujuan untuk menjaga mutu, kontinuitas, spesifikasi dan standart produk selama proses penanganan dan pengemasan. Adapun pengawasan mutu yang dilakukan oleh UD. Intisari Jaya adalah pengawasan mutu mulai dari bahan baku, tiap tahapan proses produksi dan produk akhir. Sifat dari pengawasan mutu yang diterapkan oleh UD. Intisari Jaya yaitu pencegahan dan perbaikan. Pencegahan merupakan tindakan yang sesuai dengan 
prosedur atau standart Operational Prosedur (SOP) dimana hal itu akan memperkarsai dan tindakan perbaikan, sehingga produk yang akan dihasilkan memiliki kualitas yang sangat bagus dan terjamin akan keamanannya. Adapun tindakan perbaikan dilakukan apabila penyimpagan terjadi dari persyaratan yang telah ditetapkan.

\subsection{Pengawasan Mutu Dan Pengendalian Mutu Terhadap Bahan Baku}

Pengendalian mutu terhadap bahan baku pemilihan biji melinjo, yang benar-benar sudah tua, ciri biji melinjo sudah tua kulit berwana kuning kemerahan atau merah dan bijinya keras. sehingga rasa yang dihasilkan lebih gurih dan menentukan kualitas emping melinjo, bila masih ada kulit luarnya, maka biji melinjo dipisah-pisahkan berdasarkan warnanya, yaitu ada yang berwarna hijau, kuning, dan merah. Biji melinjo yang berwarna merah merupakan bahan baku pembuatan emping yang terbaik. Sementara yang berwarna hijau dan kuning biasanya dimanfaatkan untuk sayur.

Sedangkan untuk penyimpanan bahan baku dibutuhkan tempat dengan sirkulasi udara yang lancar supaya melinjo tidak cepat busuk dikemas dalam karung agar tidak dimakan serangga atau binatang pengerak yang lainya yang dapat merusak baha baku tersebut dan selalu menjaga kebersihan tempat penyimpan ,Biji melinjo yang sudah dikupas kulit luarnya dan diangin-anginkan karna dapat menentukan kualitas Emping. Standar Penyimpanan Bahan Baku yang baik. Agar biji melinjo dapat disimpan dalam waktu yang cukup lama, caranya yaitu : biji melinjo disimpan di dalam suatu ruangan yang dilengkapi dengan pendingin atau blower. Hal ini berguna untuk,Mencegah kutu/hama pada biji melinjo, Agar biji melinjo bisa lebih kering dan Menghilangkan debu.

\subsection{Pengendalian Mutu Proses}

Pengendalian mutu selama proses perlu dilakukan agar mutu produk yang dihasilkan tetap dalam kondisi yang baik, pengendalian mutu selama proses dapat dilakukan pada setiap tahapan proses yaitu:

1. Proses penimbangan

Pengendalian mutu pada saat penimbangan ini dilakukan dengan menimbang secara teliti yaitu meletakan bahan secara bertahap kedalam timbangan. Tujuannya penimbanga agar dapat mengetahui berat bahan. penimbangan dilakukan oleh satu orang, setiap penimbangan yang ditimbang 500 gram. 


\section{Proses Penyangrai}

Pengendalian mutu pada proses penyangrai dilakukan dengan cara mengaduk-aduk biji melinjo supaya tidak gosong. Wajan yang diberi pasir bangunan,agar pada saat penumbukan tidak mudah hancur. Apabila pada saat disangrai gosong maka hasil pada saat pemipihan akan hancur, biji melinjo yang kosong dipisahkan agar tidak tercampur denga biji melinjo yang tidak gosong, Biji melinjo yang sudah dikupas kulit arinya langsung dipipih pada saat panas agar hasil emping yang diperoleh bagus sesuai dengan yang kita harapkan dan memisah hasil yang pemipihan yang kriting, Pada proses penyangrai tidak ada perlakukan yang khusus hanya saja jika pasir panasnya sudah merata baru biji melinjo disangrai, lama proses penyangrai \pm 15 menit dengan suhu $45-50^{\circ} \mathrm{C}$. Sekali penyangrai $20 \mathrm{~kg}$ menghasilkan emping $\pm 10 \mathrm{~kg}$.

3. Proses pengupasan

Pengendalian mutu pada proses pengupasan ini dilakukan dengan memisahkan kulit ari pada biji melinjo dengan cara dipipih, Alat yang digunakan masih manual yaitu batu hitam bundar dengan diameter besar $30 \mathrm{~cm}$ dan ketebalan 7 inci digunakan sebagai mengupas dengan cara dipipih dengan mengunakan batu hitam juga berbetuk segi empat panjang $9 \mathrm{~cm}$,lebar $3 \mathrm{~cm}$ dan ketebalan 2 inci, setelah itu kulit ari di pisahkan dari biji melinjo yang sudah dipipih supaya tidak tercampur dengan biji melinjo yang sudah dipipih,setelah itu dilakukan proses penumbukan

4. Proses penumbukan

Pengendalian mutu pada proses penumbukan dilakukan dengan menumbuk biji melinjo dengan cara memasang satu-persatu sampai 3 atau 4 biji melinjo agar mendapat hasil penumbukan yang seragam berbentuk bulat dengan cara membandingkan dengan hasil penumbukan yang pertama.

\section{Proses Pemberian bumbu}

Pengendalian mutu pada pemberian bumbu dilakukan dengan merendam emping melijo kedalam bumbu selama 15 menit, dengan cara meletakan bahan secara bertahap dan diaduk-aduk supaya bumbu merata. Setelah itu dilakukan proses penjemuran. 


\section{Penjemuran}

Pengendalian mutu pada proses penjemuran dilakukan dengan mengatur rege alat penjemuran yang terbuat dari bambu dan diberi alas lirik dan setiap 3 jam bahan diantur agar terkena langsung dengan sinar matahari. Pada proses penjemuran berpengaruh terhadap cepat tidaknya produk tersebut kering,pada proses penjemuran ini tidak ada perlakuan khusus untuk mengetahui kekeringan pada emping cara untuk mengetahui kering atau tidak pada emping tersebut emping yang dijemur selama \pm 10 jam jika emping dipetik mudah patah atau diresem mudah hancur maka emping tersebut tandanya sudah kering,jika pada saat penjemuran terjadi hujan maka produk dipindahkan ketempat yang teduh dan kering,supaya produk tidak basa tekena air hujan,apabila pada saat musim hujan proses penjemuran produk menjadi lama.sedangkan pada musim panas proses penjemuran cepat dalam satu hari produk bisa kering.

7. Proses pengemasan

Pengendalian mutu pada proses pengemasan dilakukan dengan menimbang bahan secara bertahap dengan berat bahan 400gram dan 500gram dan mengatur emping agar merata supaya kelihatannya menarik dan memisah emping yang utuh dari yang hancur, sedangkan pada emping yang hancur masih laku dijual dengan harga yang lebih murah.

Tabel 7: Harga jual emping melinjo yang utuh dan yang hancur

\begin{tabular}{|c|c|c|c|}
\hline \multirow{2}{*}{ Jenis Produk } & \multicolumn{3}{|c|}{ Harga Jual Rata-rata* (Rp per kg) } \\
\cline { 2 - 4 } & $\begin{array}{c}\text { Penjualan } \\
\text { Tinggi }\end{array}$ & $\begin{array}{c}\text { Penjualan } \\
\text { Sedang }\end{array}$ & $\begin{array}{c}\text { Penjualan } \\
\text { Rendah }\end{array}$ \\
\hline Emping Utuh & Rp. 24.000 & Rp. 20.000 & Rp. 16.000 \\
\hline Emping Hancur & Rp. 20.000 & Rp. 16.000 & Rp. 14.000 \\
\hline
\end{tabular}

Sumber: UD. Intisari Jaya data diolah 2009

\subsection{Pengendalian Mutu Produk Jadi}

Langkah akhir dalam pengawasan mutu adalah pengendalian mutu terhadap produk jadi. Pengendalian mutu meliputi penyimpan dan pengemasan. Untuk menghindarkan emping Melinjo dari kontaminasi selama penyimpan sementara sebelum emping melinjo 
dikemas, emping melinjo diletakan pada tempat khusus yaitu dibungkus dengan plastik berukuran besar dan di letakan dalam kardus ditutup rapat.

Proses pengemasan dilakukan dengan baik agar produk yang dikemas dapat terlindugi dan mutu tetap terjaga terutama aroma dan rasa. Emping melinjo yang sudah dikemas ditempatkan dalam ruang tempat penyimpan yang sudah dibersihkan setiap hari dengan disapu dan dipel. Pada saat produk emping belinjo akan dipasarkan, untuk menjaga agar kemasan terjaga dari serangga maupun binatang yang dapat merusak kemasan dilakukan pengemasan ulang dengan kardus dan kertas semen.Karna penyimpan produk diletakan di lantai, selain itu juga agar pada saat dalam perjalan emping tidak mudah remuk karna benturan. Dengan suhu ruangan $30^{\circ} \mathrm{C}$ dengan kelembaban 20 sehingga mutu produk tetap terjaga.

\subsection{Pemasaran Dan Distribusi}

Pemasaran adalah kegiatan manusia yang diarahkan pada usaha memuaskan keinginan dan kebutuhan melalui proses pertukaran (Kotler, 1987). Jadi pemasran bertitik tolak pada kebutuhan dan keinginan. Kebutuhan dan keinginan manusia dapat berupa benda, jasa, kegiatan, orang, tempat,gagasan, atau organisasi.

Daerah pemasaran UD. Intisari Jaya ini meliputi kawasan Yogyakarta dan luar Yogyakarta. Kawasan pemasaran wilayah Yogyakarta meliputi pasar beringharjo,pasar bantul, kawasan wilayah luar Yogyakarta meliputi pontianak, Balikpapan, Bandung, Banyuwangi, Jember, Purbalinggo dan tasik Malaya. Sistem pemasaran yang digunakan pada UD. Intisari Jaya adalah langsung bertemu dengan distributor.

Distribusi adalah kegiatan manusia yang menyalurkan barang atau jasa dari tangan produsen hingga sampai ketangan konsumen baik secara langsung maupun melalui pelatara.UD. Intisari Jaya ini mengunakan jalur distribusi yang pendek yaitu produse ke distyributor dan distributor kekonsumen.

Dalam pemasaran produk emping dibedakan menjadi dua mutu:

1. Produk dengan mutu super

Produk dengan mutu super berasa adalah produk yang dibuat pada waktu ditumbuk diberi tiga sampai empat danging buah belinjo dan setelah itu emping diberi berbangai rasa yaitu, rasa pedas, rasa manis dan rasa gurih, harga produk super ini adalah Rp. 14.000 perbungkus satu bungkusnya dengan berat 500 gram. 
2. Produk dengan mutu Biasa

Produk dengan mutu Biasa adalah produk emping yang terbuat dari buah danging melinjo pada saat penumbukan hanya diberi satu sampai dua, ciri produk emping ini adalah ukurannya bundar kecil, Harga produk dengan mutu ini adalah Rp. 11.000 per kilogramnya.

\section{KESIMPULAN}

Beberapa hal yang dapat dsimpulkan Pengendalian mutu pada proses produksi dilakukan melalui tiap tahapan proses yaitu: Proses penimbangan dilakukan dengan penimbangan 500 gr, Proses Penyangraian dengan pengaturan suhu dan lama penyangraian,Proses Pengupasan, Proses Penumbukan dilakukan membandingan dengan hasil penumbukan yang pertama ,Proses Pembumbuan dilakukan meredam bahan kedalam bak mengadukaduk sampai rata, Proses Penjemuran dilakukan membalik-balik emping setiap 3 jam dan pada Proses pengemasan dilakukan sortasi. Pengendalian mutu produk jadi dilakukan dengan penyortiran manual dan sertifikasi dari DEPKES setiap 1 tahun sekali

\section{REFERENCE}

Asauri, Sofyan. 1998. Manejemen Produk dan Operasi. Universitas Indonesia,Jakarta. Aturrosyidah. 1994. Laporan Kerja Praktek Teh Hitam di perkebunan Teh Wonosari PTP XIII. Jurusan Teknologi Industri Pertanian. Universitas Gadja Mada, Yogyakarta.

Ali, M. (2015). PENGARUH DOSIS PEMUPUKAN NPK TERHADAP PRODUKSI DAN KANDUNGAN CAPSAICIN PADA BUAH TANAMAN CABE RAWIT (Capsicum frutescens L.). JURNAL AGROSAINS: KARYA KREATIF DAN INOVATIF, 2(2), 171-178.

Ali, M. (2017). TEKNIK BUDIDAYA TANAMAN PERKEBUNAN TANAMAN TEMBAKAU.

Bappedal Profil Kecamatan Kabupaten bantul Tahun 2006 Diterbitkan BAPEDA Kabupaten Bantul.

Dale dan besterfield. 1994. Total Quality Management Edition. Prentice Hall Intenasional.

Feigenbaum. 1996. Kendali Mutu Terpadu. Hudaya Kandahjaya Jakarta:Erlangga Ir. Muryanti dan Ir. Didik Fajar, MSc. SINAR TANI edisi 3-9 oktober 2007 BPT P Yogyakarta.

M. Nurcahyo Eko. 1991. Budidaya Dan Pengolahan Melinjo (Jakarta: Penembar Swadaya). 
Mitra, A. 1993. Fudamental Of Quality Control And Improvement. Me Miilea Publishing, New York.

Prawirosantono, Suryadi. 2001. Manajemen Mutu Terpadu: Bumi Aksara. 